\title{
Self-Medication among Adults in Minia, Egypt: A Cross Sectional Community-Based Study
}

\author{
Eman R. Ghazawy, Ebtesam E. Hassan, Eman S. Mohamed*, Shimaa A. Emam \\ Public Health and Preventive Medicine Department, Faculty of Medicine, Minia University, Minia, Egypt \\ Email: ^emansameh7@yahoo.com
}

How to cite this paper: Ghazawy, E.R., Hassan, E.E., Mohamed, E.S. and Emam, S.A. (2017) Self-Medication among Adults in Minia, Egypt: A Cross Sectional Community-Based Study. Health, 9, 883-895. https://doi.org/10.4236/health.2017.96063

Received: March 18, 2017

Accepted: June 11, 2017

Published: June 14, 2017

Copyright (C) 2017 by authors and Scientific Research Publishing Inc. This work is licensed under the Creative Commons Attribution International License (CC BY 4.0).

http://creativecommons.org/licenses/by/4.0/

(c) (†) Open Access

\begin{abstract}
Self-medication may be associated with side effects and increases the chance of drug interactions and also affects the adherence to treatment and quality of life. This study aims at determining the pattern of self-medication, identifying knowledge, attitude and self-reported practices concerning the usage of the drugs and identifying demographic factors that could influence self-medication practices among the general population in El-Minia, Egypt. A community-based cross-sectional study was conducted among 422 randomly selected adults using a multi-stage random sampling technique. Data were collected by using a structured interview questionnaire. Respondents who had practiced some sort of self-medication during the past month were $73 \%$ of the sample. The commonest cause of self-medication, illness, was perceived as minor (59.7\%). The most common perceived illness for self-medication was common cold $(90.6 \%)$. Older respondents ( $>40$ years) were about twice more likely to practice self-medication than younger ones. Similarly, professionals in their work were 3.4 times more likely to practice self-medication than unemployed individuals. Self-medication is a relatively frequent problem in $\mathrm{Mi}$ nia and interventions at different levels are required.
\end{abstract}

\section{Keywords}

Self-Medication, El-Minia, Cross-Sectional, Irrational Antibiotics

\section{Introduction}

World Health Organization defines self-medication as "the use of medicinal products by the individuals to treat self-recognized disorders or symptoms. It might also involve the intermittent or continuous use of a medication prescribed by doctors for chronic or recurring diseases or symptoms" [1]. Globally, nearly half of all medicines are unreasonably used, and self-medication with antibiotics constitutes a major public health problem due to the irrational medicine use [2]. 
Serious adverse drug reactions, drug resistance, protracted illnesses and even death are a problem; moreover, the financial costs incurred by individuals and governments are often extremely high, particularly in developing countries where patients often pay for medicines out of their own pockets [3].

Self-medication is widely practiced in many developing countries; the prevalence has been reported to range from $12.7 \%$ to $95 \%$ [4] [5] [6]. The prevalence of self-medication is more in low to middle-income communities and is more common in countries where prescription legislations are not strong enough [7].

Many studies showed that there is a relationship between increased selfmedication activities and many demographic factors such as morbidity, income, education, gender, age and absence of periodic consultations [8] [9].

However, the use of non-prescription medicinal products is multi-factorial, and there is a paucity of adequate information about this issue especially in Upper Egypt. Thus the current study aims at determining the pattern of self-medication, and identifying the predictors of self-medication among adults in El-Minia, Egypt.

\section{Methods}

\subsection{Study Design and Setting}

This cross-sectional community based study was conducted in Minia city, Minia governorate, one of the Upper Egypt governorates, located $240 \mathrm{~km}$ south of Cairo, Egypt, during the period from September to November, 2016.

\subsection{Study Population and Sampling}

The required sample size was estimated based on the following conditions: assuming that the expected proportion of the population who practiced selfmedication in Egypt $(P)=50 \%$; tolerated error/margin of error $(d)=0.05$; confidence interval $(C I)=95 \%$. The following formula was used $[n=p *(1-p)$ * $(\mathrm{Za} / \mathrm{d}) 2]$. The value of $\mathrm{Z}$ is found in statistical tables which contain the area under the normal curve. Accordingly, the sample size was estimated and additions of $10 \%$ of the sample were added to guard against non-respondents rate [10].

Inclusion criteria: Finally, a total 422 adult respondents were included in the study. Persons who were unable to answer the questions or give incomplete response due to some barriers were excluded from the study. Respondents were randomly selected using a multi-stage random sampling technique. Minia governorate was found to be divided into nine districts from which Minia district was chosen randomly (first stage), then Minia city which represent the urban area in the district was chosen (second stage) which was divided into four blocks (North, East, South and West) from which the second and third blocks were chosen randomly (third stage).

The households were selected by systematic random sample by visiting every third apartment building in a randomly-selected direction asking for adults (over 18 years old). Our team met about 460, eligible persons, from whom 422 agreed to be interviewed and participate in the study (response rate 91.7\%). 
Data were collected using a structured questionnaire, filled by interviewing each individual by researchers, consisted of five sections, the first section contained questions regarding socio-demographic information such as sex, age, educational level and employment status; also they asked whether they had any chronic illness. In addition, participants were asked whether or not they have health insurance, and if they have ever practiced self-medication in general, and in the past month in particular.

The second section of the questionnaire consisted of questions related to their perception about medications, knowledge about the use of the purchased drug; and practices related to the product purchased.

In the third section of the questionnaire the respondents were requested to report on the sources of medication used for self-treatment and sources of information about such medication, also it focused on the health conditions that respondents would self-treat; this section also investigated reasons for selfmedication.

The fourth section covered another area which included antibiotic usage patterns, the respondents were asked to indicate how often they practiced selfmedication with antibiotics and how to decide which types of antibiotics were suitable for their medical conditions and how they adjust the proper course of antibiotics. The final section contained questions about respondents' beliefs and attitude concerning antibiotics self-use. This questionnaire had been tested on a small number of eligible persons as a pilot study to test the reliability of the questions and the time needed to conduct an interview. Then, proper corrections and adjustment had been fulfilled.

\subsection{Ethical Consideration}

All the procedures of this study were reviewed and approved by the Institution Review Board of the Faculty of Medicine, Minia University (Approval No.: 17-037). Prior to data collection, informed consents were obtained from all participants after supplying comprehensive information about the nature and the objectives of the study.

\subsection{Statistical Analysis}

The Statistical Program Statistical package of social science (SPSS) for Windows version 20 was used for data entry and analysis. Quantitative data were presented by mean and standard deviation, while qualitative data were presented by frequency distribution and compared by Chi-Square test. Risk ratios were estimated by calculating odds ratios (OR), and a multivariate logistic regression analysis was performed. The lowest accepted level of significance was $\leq 0.05$.

\section{Results}

This study included 422 participants; whose ages ranged from 18 to 72 years with a mean $(34.5 \pm 13.4)$. There were $45.7 \%(\mathrm{n}=193)$ males and $54.3 \%(\mathrm{n}=$ $229)$ females. From all the participants, $33.9 \%(n=143)$ currently used medica- 
tion at the time of study conduction. Eighty-eight out of those $143(61.5 \%)$ thought that they had enough knowledge about the used medication regarding; effectiveness, dose, and side effects.

Respondents who had practiced some sort of self-medication during the past month were 308 (73\%) of the sample. About $65 \%$ of respondents thought that over-the-counter medicines are as effective as those prescribed by the doctor. As for personal behavior if experienced adverse reactions, $60.4 \%$ and $26.5 \%$ of the participants said that they consult treating doctor and pharmacist respectively. About $64 \%$ reported that they discontinue medication on improvement. More than half of the participants (56.9\%) agreed that some medical complaints could be assessed and solved by a pharmacist and they said that the most common condition the pharmacist could prescribe drugs is common cold and flu which was reported by $38.8 \%$ (Table 1 ).

As regards socio-demographic characteristics, no statistically significant differences were observed between subjects who practiced self-medication and those who were not except for the occupation, where the $40.9 \%$ of persons who

Table 1. Perception and practice of self-medication among the study participants in Minia city, September to November, 2016.

\begin{tabular}{|c|c|}
\hline Variables & $\%(\mathrm{~N})$ \\
\hline \multicolumn{2}{|c|}{ Have you ever treated yourself (self-medicated)? (During last month)? } \\
\hline Yes & $73.0(308)$ \\
\hline No & $27.0(114)$ \\
\hline \multicolumn{2}{|c|}{ Do you believe that over-the-counter medicines are as effective as those prescribed by the doctor? } \\
\hline Yes & $64.9(274)$ \\
\hline No & $35.1(148)$ \\
\hline \multicolumn{2}{|c|}{ What do you do if you have experienced adverse reactions with medicines? } \\
\hline Consult treating doctor & $60.4(255)$ \\
\hline Consult Pharmacist & $26.5(112)$ \\
\hline Stop taking medications & $8.1(34)$ \\
\hline Consult family members/friends & $5.0(21)$ \\
\hline \multicolumn{2}{|l|}{ Duration of using prescribed medications? } \\
\hline Until symptoms subsides & $64.2(271)$ \\
\hline Up to given regimen & $35.8(151)$ \\
\hline \multicolumn{2}{|l|}{ Do you give advice to others as regard medications? } \\
\hline Yes & $38.9(164)$ \\
\hline No & $61.1(258)$ \\
\hline \multicolumn{2}{|c|}{ In your opinion, is there some medical complaints can be assessed/solved by a pharmacist? } \\
\hline Agree & $56.9(240)$ \\
\hline Don't agree & $43.1(182)$ \\
\hline \multicolumn{2}{|c|}{ What are the conditions which pharmacist could prescribe drugs? $(n=240)$} \\
\hline Common cold and flu & $38.8(93)$ \\
\hline Cough & $22.9(55)$ \\
\hline Headache & $10.4(25)$ \\
\hline Gastrointestinal (dyspepsia, constipation, diarrhea) & $9.2(22)$ \\
\hline Dental pain & $6.3(15)$ \\
\hline Muscle and joint pain & $5.0(12)$ \\
\hline Fever & $4.6(11)$ \\
\hline Allergic dermatitis & $2.9(7)$ \\
\hline
\end{tabular}


practice self-medication were professional worker compared to $35 \%$ of persons not practicing self-medication ( $\mathrm{p}=0.0003$ ) (Table 2).

Regarding the sources of medicinal products used by respondents who practiced self-medication it was found that drugs purchased from private pharmacies were the most commonly used sources of self-medication, reported by the majority of self-medicated individuals (86.7\%), and followed by the use of left-over medicine (79.9\%). Those who obtained medications from their relatives or friends constituted $22.7 \%$ of self-medicated respondents (Table 3 ).

The commonest source of information about the drugs used for self-medication was the pharmacists, reported by about $92 \%$ of respondents. This was followed by respondents' experiences or knowledge from previous episodes (84.7\%). Internet and advertisements were the least common source of information, reported by only $6.5 \%$ of respondents.

The commonest reason for self-medication was that the illness was perceived as minor (59.7\%). More than $40 \%$ of self-medicated respondents indicated that previous experience with the treatment was a reason for self-medication. About one-third of self-medicated respondents $(29.8 \%)$ indicated that they did so because they lacked the time to visit formal health care facilities. One-quarter of self-medicated participants indicated that the cost of consultations with the doctor was a reason for self-medication (Table 3).

The most common perceived illnesses for self-medication were common cold (90.6\%), headache $(71.1 \%)$, cough $(69.5 \%)$, sore throat $(68.5 \%)$, toothache (38.9\%) and 50.3\% represent other reasons mainly GIT problems.

Table 2. Socio-demographic characteristics of the study participants in Minia city, September to November, 2016.

\begin{tabular}{|c|c|c|c|}
\hline $\begin{array}{l}\text { Socio demographic } \\
\text { characteristics }\end{array}$ & $\begin{array}{l}\text { practicing self-medication } \\
\qquad(\mathrm{n}=308) \%(\mathrm{n})\end{array}$ & $\begin{array}{l}\text { Not practicing self-medication } \\
\qquad(\mathrm{n}=114) \%(\mathrm{n})\end{array}$ & P-value \\
\hline \multicolumn{4}{|l|}{ Age } \\
\hline$<20$ years & $13.0(40)$ & $14.0(16)$ & 0.1 \\
\hline $20-30$ years & $33.4(103)$ & $38.6(44)$ & \\
\hline $30-40$ years & $24.7(76)$ & $14.9(17)$ & \\
\hline$>40$ years & $28.9(89)$ & $32.5(37)$ & \\
\hline \multicolumn{4}{|l|}{ Sex } \\
\hline Males & $46.8(144)$ & $43.0(49)$ & 0.4 \\
\hline Females & $53.2(164)$ & $57.0(65)$ & \\
\hline \multicolumn{4}{|l|}{ Educational level } \\
\hline$<$ High school & $14.3(44)$ & $14.0(16)$ & 0.9 \\
\hline$\geq$ High school & $85.7(264)$ & $86.0(98)$ & \\
\hline \multicolumn{4}{|l|}{ Occupation } \\
\hline Unemployed & $27.3(84)$ & $44.7(51)$ & 0.003 \\
\hline Manual work & $18.5(57)$ & $14.0(16)$ & \\
\hline Clerical work & $13.3(41)$ & $6.1(7)$ & \\
\hline Professional & $40.9(126)$ & $35.2(40)$ & \\
\hline \multicolumn{4}{|l|}{ Family members } \\
\hline$<4$ members & $24.4(75)$ & $25.4(29)$ & 0.8 \\
\hline$\geq 4$ members & $75.6(233)$ & $74.6(85)$ & \\
\hline
\end{tabular}

${ }^{\star}$ Chi-square test was use. 
Table 3. Sources of medications and information on self-medication and reasons for using self-medication during the last month, among adults, Minia city, September to November, $2016(\mathrm{n}=308)$.

\begin{tabular}{lc}
\hline \multicolumn{1}{l}{ Variables } & $\%(\mathbf{n})^{*}$ \\
\hline $\begin{array}{l}\text { Sources of medications } \\
\text { Private pharmacy }\end{array}$ & $267(86.7)$ \\
Leftover prescription medication & $246(79.9)$ \\
Family/friends & $70(22.7)$ \\
\hline Sources of information on self-medication & \\
Pharmacists & \\
Previous prescription & $284(92.2)$ \\
Relatives/ friends & $261(84.7)$ \\
Mass media & $112(36.4)$ \\
Other (internet, advertisements) & $35(11.4)$ \\
\hline $\begin{array}{l}\text { Reasons for using self-medication } \\
\text { The perceived problem as minor not requiring medical attention }\end{array}$ & $20(6.5)$ \\
Know the treatment from previous prescription & \\
Lack of time to attend health care facilities & $184(59.7)$ \\
Confidence in the pharmacist & $126(40.9)$ \\
Cost of consultations with the doctor & $92(29.8)$ \\
Others (advice from family member, have my own stock at home) & $82(26.6)$ \\
\hline Most common perceived illnesses for self-medication & $77(25.0)$ \\
Common cold & $42(13.6)$ \\
Headache & \\
Cough & \\
Toothe throat & \\
Others (mainly GIT) & $279(90.6)$ \\
\hline
\end{tabular}

aNumbers do not add to $100 \%$ as respondents might have more than 1 reason.

About $62 \%$ of the respondents used un-prescribed antibiotics for any illness, $47.3 \%$ used antibiotics more than once during the past month prior. About $44 \%$ of them decide the type of antibiotic which needed for his illness from previous prescription. About $42 \%$ of the participants know the proper dose of antibiotic by asking the pharmacist (Table 4 ).

Thirty-six percent of the respondents were aware that inappropriate use of antibiotics leads to antibiotic resistance and $63.5 \%$ knew that antibiotics could cause adverse drug reactions. Furthermore, $59.7 \%$ used the antibiotics only till disappearance of symptoms and $73 \%$ of participants thought that antibiotics are being effective in treating both bacterial and viral infections (Table 5).

Table 6 shows the multivariable-adjusted ORs (95\% CIs) for factors associated with practicing of self-medication. The practice of self-medication among older respondents ( $>40$ years) was 2.28 times that of under 20 years old, and 3.4 times among professional workers than unemployed individuals, $(\mathrm{OR}=2.28$, 95\% CI: 1.12 - 4.67), and (3.44, 95\% CI: 1.40 - 9.09) respectively. Additionally, we found that large family size was a significant predictor of self-medication $(\mathrm{OR}=2.04,95 \%$ CI: 1.84 - 2.33). 
Table 4. Past experiences of participants with antibiotic self-medication, Minia city, September to November, $2016(\mathrm{n}=260)$.

\begin{tabular}{lc}
\hline \multicolumn{1}{c}{ Variables } & $\%(\mathrm{n})$ \\
\hline Participants used un-prescribed antibiotics for any illness & $260(61.6)$ \\
\hline $\begin{array}{l}\text { How often did you do that in the last month? } \\
\text { Once }\end{array}$ & $137(52.7)$ \\
More than once & $123(47.3)$ \\
\hline How do you decide that antibiotic is needed for your illness? & \\
Know the treatment from previous prescription & $115(44.2)$ \\
Ask pharmacist & $78(30.0)$ \\
Others (advice from others) & $67(25.8)$ \\
\hline How you know the proper dose of the antibiotic? & $110(42.3)$ \\
Ask the pharmacist & $107(41.2)$ \\
My previous experience & $31(11.9)$ \\
Read instructions & $7(2.7)$ \\
Ask the person who advised me & $5(1.9)$ \\
By guessing the dosage by myself & \\
\hline
\end{tabular}

Table 5. Knowledge concerning antibiotic self-medication among adults, Minia city, September to November, $2016(\mathrm{n}=422)$.

$\begin{aligned} & \text { Do you know that inappropriate use of antibiotics leads to } \\
& \text { antibiotic resistance? }\end{aligned}$
$\begin{aligned} & \text { Yes } \\
& \text { No }\end{aligned}$
$\begin{aligned} & 152(36.0) \\
& \text { How do you know the appropriate period of antibiotic use? }\end{aligned}$
$\begin{aligned} & \text { Period indicated by physician or pharmacist } \\
& \text { Period indicated in drug leaflet }\end{aligned}$
$\begin{aligned} & \text { Antibiotics used until relief of symptoms } \\
& \text { Do you think that antibiotics are effective in the treatment of }\end{aligned}$
$\begin{aligned} & \text { both bacterial and viral infection? } \\
& \text { Agree }\end{aligned}$
$\begin{aligned} & \text { Don't agree } \\
& \text { Do you know if self-medication with antibiotics may result } \\
& \text { in adverse effects? }\end{aligned}$
$\begin{aligned} & \text { Yes } \\
& \text { No }\end{aligned}$
\begin{tabular}{l} 
I don't know \\
\hline
\end{tabular}

\section{Discussion}

The prevalence of self-medication found in this study was $73 \%$. Our estimates are lower than the figures reported from the previous study conducted in Alexandria in 2009 ; it was found that $81.1 \%$ of participant practiced self-medication [11]. Similarly, in Karachi, a study was conducted and it was found that selfmedication was prevalent among $76 \%$ of the population [12]. On the contrary, another study among Jordanian population showed lower prevalence (42.5\%) [13]. 
Table 6. Logistic regression analysis of factors independently associated with self-medication among participants $(n=422)$.

\begin{tabular}{|c|c|c|}
\hline Characteristic & OR ( $95 \% \mathrm{CI})$ & $P$ value \\
\hline \multicolumn{3}{|l|}{ Age } \\
\hline$<20$ years & (reference) & \\
\hline 20 - 30 years & $0.49(0.21-1.16)$ & 0.1 \\
\hline $30-40$ years & $1.30(0.67-2.51)$ & 0.4 \\
\hline$>40$ years & $2.28(1.12-4.67)$ & 0.02 \\
\hline \multicolumn{3}{|l|}{ Sex } \\
\hline Males & (reference) & \\
\hline Females & $1.03(0.63-1.71)$ & 0.8 \\
\hline \multicolumn{3}{|l|}{ Marital status } \\
\hline Unmarried & (reference) & \\
\hline Married & $1.51(0.79-2.85)$ & 0.2 \\
\hline \multicolumn{3}{|l|}{ Educational level } \\
\hline$<$ High school & (reference) & \\
\hline$\geq$ High school & $0.74(0.34-1.56)$ & 0.4 \\
\hline \multicolumn{3}{|l|}{ Occupation } \\
\hline Unemployed & (reference) & \\
\hline Manual work & $1.18(0.60-2.34)$ & 0.6 \\
\hline Clerical work & $1.42(0.63-3.21)$ & 0.3 \\
\hline Professional & $3.44(1.40-9.09)$ & 0.01 \\
\hline \multicolumn{3}{|l|}{ Family members } \\
\hline$<4$ members & (reference) & \\
\hline$\geq 4$ members & $2.04(1.84-2.33)$ & 0.008 \\
\hline \multicolumn{3}{|l|}{ Having chronic illness } \\
\hline No & (reference) & \\
\hline Yes & $1.35(0.39-1.44)$ & 0.3 \\
\hline \multicolumn{3}{|c|}{ Perceived access to health care (having insurance) } \\
\hline No & (reference) & \\
\hline Yes & $1.47(0.88-2.50)$ & 0.3 \\
\hline
\end{tabular}

About $65 \%$ of respondents thought that over-the-counter medicines are as effective as those prescribed by the doctor. The finding was approximate to that reported by Hassali et al. [14] in Malaysia (62.7\%). As for personal behavior if experienced adverse reactions with medicines, $60.4 \%$ and $26.5 \%$ of the participants said that they consult treating doctor and pharmacist respectively, this is in accordance with a study conducted in Danish population which revealed that $73 \%$ and $35.2 \%$ consulting doctor and pharmacist respectively if experienced adverse reactions [15].

In the current study discontinuation of medicine on improvement was reported by $64.2 \%$ of respondents. Sallam et al. (2009) reported that $69.3 \%$ of participants in his study used medicine until complaint disappears [11].

More than half of the participants (56.9\%) agreed that some medical complaints could be assessed and solved by a pharmacist and they said that the common condition the pharmacist could prescribe drugs is common cold and flu which was reported by $38.8 \%$. A study among Indian population reported 
that $69 \%$ of respondent agree to consult the pharmacist when complaining common condition as common cold, headache and flu [16].

\subsection{Sources of Medications and Information on Self-Medication}

Likewise findings from several studies [13] [17] [18], our study revealed that drugs purchased from private pharmacies were the most commonly used sources of self-medication, reported by the majority of self-medicated individuals (86.7\%), and the use of leftover medicine was also prevalent and reported by about $80 \%$ of respondents. Easy accessibility of medicines from the pharmacy without prescription could explain the high percentage of purchasing from private pharmacies as a major source of the practice of self-medication. Also, keeping medicine at home is an important concern lead to increase the possibility of self-medication and mistakes in proper consumption.

Regarding the source of information about the drugs used for self-medication, the commonest source of information was the pharmacists, reported by about $92 \%$ of respondents. This was followed by respondents' experiences or knowledge from previous episodes (84.7\%). The overall sources of information show that self-medication practices among adults in this study are not influenced by advertisements or the Internet; they were the least common source of information, reported by only $6.5 \%$ of respondents. which was similar to a study conducted in Saudi Arabia [18], and revealed that $74 \%$ of participant had the source of information from pharmacist followed by respondents' experiences (50.8\%) and $16.4 \%$ from Internet and advertisements. This, however, is in contrast to a study conducted by Chui et al. [19] that showed that more than half of the participants never consulted a pharmacist on how to manage minor disorders.

\subsection{Reasons for Using Self-Medication}

The current study revealed that the commonest reason for self-medication was that the illness was perceived as minor (59.7\%) followed by previous experience with the treatment (40\%). About one-third of self-medicated respondents (29.8\%) indicated that they did so because they lacked the time to visit formal health care facilities. One-quarter of self-medicated participants indicated that the cost of consultations with the doctor was a reason for self-medication. Above findings comparable to the results of a study performed by Sallam et al., 2009 (11) in Alexandria who found that the commonest cause was the illness perceived as minor (44.5\%), followed by previous experience with the treatment (31\%) and $24 \%$ indicated for other reasons. Another study conducted by Swetha $\mathrm{R}$ and Usha $\mathrm{R}$ revealed that long wait at clinics (31.6\%), mild nature of the illness (27.56\%) and financial problems (17.35\%) were most common reasons for adopting self-medication among Indian population [20].

The most common perceived illnesses for self-medication were common cold (90.6\%), followed by headache $(71.1 \%)$ then cough by (69.5\%). This is similar to a finding by Noori [21] which showed that common cold has a high percent of the symptoms that led to self-medication. However, a study conducted in Sri 
Siddhartha, India showed that cough, headache and fever were common symptoms for which participants practiced self-medication [20].

\subsection{Antibiotic Self-Medication}

Self-medication with antibiotics was reported by 260 of 422 respondents (61.6\%). This is in agreement with Khan et al., 2011 who found that $69 \%$ of the studied participant used antibiotics without a prescription [22]. Some other studies on self-medication with antibiotics have reported prevalence rates of $74 \%$ in Sudan [23], 46\% in Jordan [24] and 78\% in Greece [25].

Among the 260 respondents who used to take unprescribed antibiotics, $47.3 \%$ had used antibiotics more than once during the past month. About $44.2 \%$ had previous experience in using such antibiotics, $42.3 \%$ of the participants know the proper dose of antibiotic by asking the pharmacist. These findings were comparable to the results of a study performed by Widayati et al., 2011 [26] who found that $54 \%$ decide the type of antibiotic based on previous prescription and $52 \%$ know their information from the pharmacist.

Unfortunately, only $36 \%$ of the respondents were aware that inappropriate use of antibiotics leads to antibiotic resistance. Contradictory, Noori [21] reported $59.6 \%$ in Kufa, Iraq was aware of the antibiotic resistance due to irrational use of antibiotics. More than half (59.7\%) believed that antibiotics should be used until relief of symptoms. This was high compared with a study carried out in Lithuania [27], where $10 \%$ said that antibiotics should be used until relief of symptoms.

The current study revealed that (73\%) of the sample thought that antibiotics are effective in the treatment of both bacterial and viral infection. Pavyde et al. [27] showed that Almost half of the respondents incorrectly identified antibiotics as being effective either in treating viral $(26.0 \%)$ or mixed (bacterial and viral) infections (21.7\%).

About two-thirds of the respondents (63.5\%) knew that antibiotics could cause adverse drug reactions. This was low compared with a study carried out in Lithuania [27], where the majority of the respondents (92.9\%) knew that fact.

\subsection{Factors Associated with Self-Medication}

This result highlights the associated risk between self-medication practice and increasing age ( $>40$ years, $(\mathrm{OR}=2.28$; $95 \% \mathrm{CI} 1.12-4.67)$ and professionally employed participant ( $\mathrm{OR}=3.44 ; 95 \% \mathrm{CI} 1.40$ - 9.09). This is similar to a finding by Moraes et al. [28] which showed that increasing age $(\mathrm{OR}=1.24)$, professional employment $(\mathrm{OR}=1.21)$ were significant predictors of self-medication. Also, we revealed that the bigger the family size the more use of self-medication $(\mathrm{OR}=$ 2.04; 95\% CI 1.84 - 2.33). This is in accordance with Widayati et al., 2011 (26) who found that increasing the family size ( $>4$ members) is an important risk factor for self-use of medicine ( $\mathrm{OR}=1.2)$.

However we found no significant association between being covered by health insurance and practicing self-medication, this was in line with study conducted by Sarahroodi et al. (2012) who reported no statistically significant difference 
between self-medication and having or not having medical insurance [29]. On contrary, Widayati et al. (2011) [26] found that Indonesian who had perceived access to health care (having insurance) were 1.47 times more likely to selfmedicate than those who reported no access to health care $(\mathrm{OR}=1.47)$.

\section{Limitations}

The most important limitation is that the answers reported by the respondents cannot be validated. Economic conditions not investigated in the current study. Perception and practices among rural residents and the impact of socioeconomic status on self-medication need to be investigated in further studies.

\section{Conclusion}

The results of this study confirm that self-medication is a relatively frequent problem in our community which could result in an increase in drug induced disease and in wasteful public expenditure. This indicates the need for change in the perception and practices towards the safe use of medicines. Interventions at different levels are required in order to reduce the frequency of medication misuse. The community should be educated regarding appropriate use of drugs and the adverse effect of drugs; this would require massive health education aimed at behavioral changes and strict precautions about the irrational use of antibiotics.

\section{Acknowledgements}

The authors are very much grateful to all participants of the study for their kind cooperation.

\section{References}

[1] World Health Organization (2000) Guidelines for the Regulatory Assessment of Medicinal Products for Use in Self-Medication. http://apps.who.int/medicinedocs/en/d/Js2218e/

[2] Donkor, E., Tetteh-Quarcoo, P., Narty, P. and Agyeman, I. (2012) Self-Medication Practices with Antibiotics among Tertiary Level Students in Accra, Ghana: A Cross-Sectional Study. International Journal of Environmental Research and Public Health, 9, 3519-3529. https://doi.org/10.3390/ijerph9103519

[3] Jha, N., Bajracharya, O. and Shankar, P. (2013) Knowledge, Attitude and Practice towards Medicines among School Teachers in Lalitpur District, Nepal before and after an Educational Intervention. BMC Public Health, 13, 2-11. https://doi.org/10.1186/1471-2458-13-652

[4] Fuentes, A.K. and Villa, Z.L. (2008) Analysis and Quantification of Self-Medication Patterns of Customers in Community Pharmacies in Southern Chile. Pharmacy World and Science, 30, 863-868. https://doi.org/10.1007/s11096-008-9241-4

[5] Figueiras, A., Caamano, F. and Gestal, O.J. (2000) Socio-Demographic Factors Related to Self-Medication in Spain. European Journal of Epidemiology, 16, 19-26. https://doi.org/10.1023/A:1007608702063

[6] Kasilo, O.J., Nhachi, C.F. and Mutangadura, E.F. (1991) Epidemiology of House- 
hold Medications in Urban Gweru and Harare. Central African Journal of Medicine, 37, 167-171.

[7] Sheraz, J.K., Amanullah, S.K. and Nazeer, S. (2011) Self-Medication with Antibiotics in Urban Area of Peshwar. Gomal Journal of Medical Sciences, 9, 19-22.

[8] Caulin, C. and Cranz, H. (2000) Self-Medication: Is Regulation Needed from Whom? Thérapie, 55, 547-553.

[9] Somsen, G.A. and Schut, N.H. (1998) Acute Renal Failure Due to Self-medication. Netherlands Journal of Medicine, 53, 45-46. https://doi.org/10.1016/S0300-2977(98)00049-7

[10] Lwanga, S. and Lemeshow, S. (1991) Sample Size Determination in Health Studies. A Practical Manual. http://www.tbrieder.org/publications/books english/lemeshow samplesize.pdf

[11] Sallam, S.A., Khallafallah, N.M., Ibrahim, N.K. and Okasha, A.O. (2009) Pharmaco Epidemiological Study of Self-Medication in Adults Attending Pharmacies in Alexandria, Egypt. Eastern Mediterranean Health Journal, 15, 683-691.

[12] Yousef, A.M., Al-Bakri, A.G., Bustanji, Y. and Wazaify, M. (2008) Self-Medication Patterns in Amman, Jordan. Pharmacy World \& Science, 30, 24-30. https://doi.org/10.1007/s11096-007-9135-x

[13] Zafar, S.N., Syed, R. and Waqar, S. (2008) Prescription of Medicines by Medical Students of Karachi, Pakistan: A Cross-Sectional Study. BMC Public Health, 19, 162-166. https://doi.org/10.1186/1471-2458-8-162

[14] Hassali, M., Shafie, A., Al-Qazaz, H., Tambyappa, J., Palaian, S. and Hariraj, V. (2011) Self-Medication Practices among Adult Population Attending Community Pharmacies in Malaysia: An Exploratory Study. International Journal of Clinical Pharmacy, 33, 794-799. https://doi.org/10.1007/s11096-011-9539-5

[15] Frøkjær, B., Bolvig, T., Griese, N., Herborg, H. and Rossing, C. (2012) Prevalence of Drug-Related Problems in Self-Medication in Danish Community Pharmacies. Innovations in Pharmacy, 3, 1-10.

[16] Aishwaryalakshmi, K., Sasikala, B., Sreelalitha, N., Vigneshwaran, E. and Padmanabha, Y.R. (2012) Assessment of Knowledge Perception and Attitudes on Medications in General Population. Indian Journal of Pharmacy Practice, 5, 75-78.

[17] Sharif, S.I., Ibrahim, O.H., Mouslli, L. and Waisi, R. (2012) Evaluation of SelfMedication among Pharmacy Students. American Journal of Pharmacology and Toxicology, 7, 135-140. https://doi.org/10.3844/ajptsp.2012.135.140

[18] Alghanim, S.A. (2011) Self-Medication Practice among Patients in a Public Health Care System. Eastern Mediterranean Health Journal, 17, 409-416.

[19] Chui, W.K. and Li, S.C. (2005) Advice-Giving on Self-Medication: Perspectives of Community Pharmacists and Consumers in Singapore. Journal of Clinical Pharmacy and Therapeutics, 30, 225-231. https://doi.org/10.1111/j.1365-2710.2005.00637.x

[20] Swetha, R. and Usha, R. (2016) Study of Self-Medication Pattern among Adults in Tumkur City. Journal of Preventive Medicine and Holistic Health, 2, 13-16. https://doi.org/10.5958/2454-6712.2016.00004.3

[21] Noori, A.R. (2010) Irrational Self-Medication of Antibiotic in University of Kufa in an Najaf. Medical Journal of Babylon, 7, 1-2.

[22] Khan, S.J., Amanullah, Khan, S. and Shah, N. (2011) Self-Medication with Antibiotics in Urban Areas of Peshawar. Journal of Medical Sciences, 9, 19-22.

[23] Awad, A., Eltayeb, I., Matowe, L. and Thalib, L. (2005) Self-Medication with Antibiotics and Antimalarials in the Community of Khartoum State, Sudan. Journal of 
Pharmaceutical Sciences, 8, 326-331.

[24] Al-Bakri, A., Bustanji, Y. and Yousef, A. (2005) Community Consumption of Antibacterial Drugs within the Jordanian Population: Sources, Patterns and Appropriateness. International Journal of Antimicrobial Agents, 26, 389-395.

https://doi.org/10.1016/j.ijantimicag.2005.07.014

[25] Skliros, E., Merkouris, P., Papazafiropoulou, A., Gikas, A., Matzouranis, G., Papafragos, C., et al. (2010) Self-medication with Antibiotics in Rural Population in Greece: A Cross-Sectional Multicenter Study. BMC Family Practice, 11, 58. https://doi.org/10.1186/1471-2296-11-58

[26] Widayati, A., Suryawati, S., Crespigny, C. and Hiller, J. (2011). Self-Medication with Antibiotics in Yogyakarta City Indonesia: A Cross-Sectional Population-Based Survey. BMC Research Notes, 4, 491. https://doi.org/10.1186/1756-0500-4-491

[27] Pavydè, E., Veikutis, V., Mačiulienè, A., Mačiulis, V., Petrikonis, K. and Stankevičius, E. (2015) Public Knowledge, Beliefs and Behavior on Antibiotic Use and Self-Medication in Lithuania. International Journal of Environmental Research and Public Health, 12, 7002-7016. https://doi.org/10.3390/ijerph120607002

[28] Moraes, A., Delaporte, T., Molena-Fernandes, C. and Falcão, M. (2011) Factors Associated with Medicine Use and Self-Medication Are Different in Adolescents. Clinics (Sao Paulo), 66, 1149-1155. https://doi.org/10.1590/S1807-59322011000700005

[29] Sarahroodi, S., Maleki-Jamshid, A., Sawalha, A.F., Mikaili, P. and Safaeian, L. (2012) Pattern of Self-Medication with Analgesics among Iranian University Students in Central Iran. Journal of Family and Community Medicine, 19, 125-129. https://doi.org/10.4103/2230-8229.98302

\section{Submit or recommend next manuscript to SCIRP and we will provide best service for you:}

Accepting pre-submission inquiries through Email, Facebook, LinkedIn, Twitter, etc. A wide selection of journals (inclusive of 9 subjects, more than 200 journals) Providing 24-hour high-quality service User-friendly online submission system Fair and swift peer-review system Efficient typesetting and proofreading procedure Display of the result of downloads and visits, as well as the number of cited articles Maximum dissemination of your research work

Submit your manuscript at: http://papersubmission.scirp.org/ Or contact health@scirp.org 